\title{
Analisis Barrier to Adoption (Hambatan Untuk Mengadopsi) Aplikasi Ojek Online oleh Ojek Konvensional
}

\author{
Roland H. Pakpahan dan Henry Pandia \\ Fakultas Teknologi Informasi, Universitas Advent Indonesia
}

\begin{abstract}
Abstrak
Pada saat ini ojek merupakan salah satu transportasi alternatif yang banyak dipilih oleh kalangan masyarakat, hal ini dikarenakan ojek dapat menjadi solusi transportasi untuk menghindari kemacetan yang ada di tengah kota. Dalam perkembangan teknologi munculnya layanan baru berupa ojek online yang memberikan kemudahan kepada masyarakat dengan menggunakan aplikasi yang terintegrasi dengan perusahan, sehingga kemudahan yang ditawarkan oleh ojek online terkesan menenggelamkan keberadaaan ojek konvensional yang menimbulkan kerugian terhadap pendapatan mereka. Penelitian ini mencari hambatan yang di alami ojek konvensional untuk bergabung dengan ojek online. Tujuan dalam penelitian ini adalah untuk mengetahui apa saja barrier to adoption teknologi ojek online dikalangan para pengemudi ojek konvensional, dan mencari solusi mengurangi barrier to adoption teknologi ojek online dikalangan ojek konvensional. Adapun hambatan yang ditemukan dari 6 komponen yaitu, perilaku dan perilaku kepada penumpang, teknologi, finansial, kelengkapan berkendara, informasi dan paguyuban. Keenam komponen tersebut diukur terhadap 36 responden di wilayah Bandung dan sekitarnya, dimana responden adalah pengemudi ojek konvensional. Data dikumpulkan melalui wawancara dan penyebaran kuesioner, untuk data yang diolah. Penelitian ini adalah penelitian deskriptif yang menggambarkan objek atau peristiwa yang bertujuan untuk mengetahui keadaan yang terjadi pada saat sekarang untuk memperoleh gambaran serta solusi untuk barrier business yang terjadi pada ojek konvensional. Penulis mengambil kesimpulan bahwa dari semua komponen kuesioner, payuguban adalah hambatan yang paling besar untuk pengemudi ojek konvensional untuk mengadopsi teknologi ojek online, dimana mereka masih nyaman menunggu penumpang di pangkalan karena kebersamaan terhadap sesama pengemudi dianggap memperkecil persaingan dalam mencari penumpang, berdasarkan kesimpulan yang diperoleh dari hasil data, maka penulis memberi saran untuk mengurangi hambatan mengadopsi aplikasi online bahwa pendidikan adalah faktor yang cukup penting untuk meningkatkan kemajuan berfikir dari masyarakat dan salah satu modal untuk mempunyai suatu pekerjaan yang produktif dan efisien.
\end{abstract}

Kata - kata kunci: Hambatan, adopsi aplikasi, Ojek Online, paguyuban

\section{Barrier to Adoption Analysis of Online Motorcycle Taxi Application by Conventional Motorcycle Taxi}

\begin{abstract}
At this moment, ojek is one of alternative transportation that has been choosed by most people, this is because ojek offered a solution for trafics in capital city. The development of technology by the appereance of online ojek that give convenience to consumen who use application that intregrated to the company, so the convenience that offered by online ojek seems like drown conventional ojek and cause them loss income. This reseach is to find the obstacles for conventional ojek driver to join online ojek. The purpose for this reseach is to know what are the barrier to adopt online ojek application in the circles of conventional ojek driver and to find solution to reduce the barrier to adoption to technology by conventional ojek driver. As for as we found 6 components for the barrier, such as behavior and consumen behavior, technology, financial, completeness for ride, information and paguyuban. the sixth component measured on 36 respondents in Bandung area, and all the respondent is ojek conventional drivers. Collecting data by interview and spreading questionnaire for processing data. This research is descriptive research that show object and event to know the circumstances that happend now and to illustrate the solution for barrier of aplication adoption by conventional ojek driver. Author take conclution based on questionnaire that the biggest barrier component from all component is paguyuban to adopt online application, where as they still comfortable to wait for their customer in their spot, this cause by the feeling togetherness each other and it reduces competition, based on the analysis of data, author give some suggestion to reduce the barrier to adopt online aplication that is education is
\end{abstract}


important fact to increase how people think, from society it is one of the important things to become a productive and eficient work in the future.

Keywords: Barrier, aplication adoption, Online Ojek, paguyuban

\section{Pendahuluan}

Pada saat ini ojek merupakan salah satu transportasi alternatif yang banyak dipilih oleh kalangan masyarakat, hal ini dikarenakan ojek dapat menjadi solusi untuk menghindari kemacetan yang ada di tengah kota yang mampu memberikan keuntungan bagi golongan masyarakat tertentu yang bersifat rutin maupun berkala dalam penunjang pergerakan transportasi.

Dalam perkembangan teknologi munculnya layanan baru berupa ojek online hanya dengan mendownload aplikasi dari app store dan google play di smartphone para pengguna sudah dapat menikmati layanan ojek dengan mudah. Pengguna hanya perlu memesan layanan ojek dari aplikasi tanpa harus pergi ke pangkalan ojek. Secara tidak langsung ojek online bukan hanya memberikan manfaat terhadap masyarakat tetapi "membantu" pemerintah dalam mengatasi kebutuhan masyarakat di dalam transportasi umum.(Hamri Gusman Zakaria Hal : 25)

Meski demikian, masih kurangnya ojek konvensional untuk bergabung mengadopsi aplikasi online dengan alasan, kurang berminat dengan aturan sistem bagi hasil yang diterapkan oleh penyedia aplikasi, layanan ojek konvensional lebih lama dikalangan masyarakat dibandingkan ojek online yang tidak mudah mengubah sistem ojek konvensional, kurang menyukai adanya sistem promosi yang menurunkan penghasilan ojek konvensional, dan masih banyak ojek konvensional belum paham dalam menggunakan aplikasi smartphone sehingga alasan tersebut menjadikan hambatan terhadap ojek konvensional untuk mengadopsi aplikasi online.(MB.COM).

\section{Landasan Teori Ojek}

Menurut Annor (2016: h.8) ojek adalah sarana transportasi umum dengan sistem paratransit yang memberikan arti dan makna mengenai angkutan tersebut. Menurut kamus besar umum Bahasa Indonesia ojek adalah sepeda motor yang dibuat menjadi kendaraan umum yang mengantarkan pengguna jasa ke tempat tujuan. Tetapi menurut kamus Bahasa Indonesia (1991) karangan DRS. Petter Salim dan Yenny Salim menyebutkan bahwa ojek adalah sepeda motor roda dua atau tiga tanpa rumah-rumah baik dengan kereta samping yang dipergunakan sebagai sarana angkutan umum.

\section{Ojek Online}

Menurut Ahrika (2017:h.4) ojek online merupakan transportasi yang sama dengan ojek pada umumnya, yang menggunakan sepeda motor sebagai sarana pengangkutan, dengan demikian ojek online lebih maju karena terintegrasi dengan kemajuan teknologi aplikasi. Ojek online memanfaatkan aplikasi smartphone yang memudahkan pengguna jasa dalam memanggil pengemudi ojek, tidak hanya dalam hal sebagai sarana pengangkutan orang dan barang namun juga dimanfaatkan untuk membeli barang bahkan memesan makanan sehingga masyarakat dalam global di kota-kota besar dengan kegiatan yang sangat padat, tidak dapat dipungkiri dengan masalah kemacetan selalu menjadi polemik, ojek online hadir memudahkan masyarakat dalam melakukan kegiatan sehari-hari dengan mengedepankan teknologi yang semakin maju.

Dalam aplikasi yang sudah di unduh customers sudah dapat mengetahui jarak, lama pemesanan, harga, nama orang yang menjemput, serta perusahaan pengelolanya. Seluruh indentitas pengendara dapat diketahui secara pasti karena perusahaan pengelola telah melakukan proses vertifikasi terlebih dahulu sebelum melakukan kerjasama kemitraan. Terdapat beberapa hal yang bisa diketahui oleh pelanggan saat memesan ojek online yaitu:

1. Identitas pelanggan

2. Mudah menemukan tukang ojek

3. Tidak perlu adanya tawar menawar

4. Bisa menemukan pengendara yang tahu lokasi tujuan

5. Mengetahui harga sebelum berangkat

6. Terdapat lampiran foto pengendara

Sedangkan dari sisi pengendara atau rider, tukang ojek yang selama ini harus menawarkan jasa ke pelanggan yang lewat kini tidak perlu lagi menawarkan jasanya. Yang perlu dilakukan oleh seorang pengemudi ojek online adalah memutuskan dan menerima atau tidak menerima tawaran dari customers yang berhubungan langsung dengan perusahaan pengelola. Kelebihan yang dapat dirasakan oleh 
pengendara atau driver ojek online tidak adanya proses tawar menawar, tidak adanya proses menanyakan tujuan, serta tidak ada lagi kepastian harga. Semuanya sudah ditentukan lewat smartphone.

Driver atau pengendara ojek online memiliki kelebihan seperti:

1. Tidak perlu menawarkan jasanya kepada pengguna jasa dengan smartphone pengemudi mudah di dapatkan.

2. Tidak perlu mencari tempat pangkalan untuk menunggu pengguna jasa.

3. Tidak ada penawaran terhadap pelanggan yang berlebihan karena sudah tercantum harga yang disesuaikan oleh aplikasi smartphone.

4. Mengetahui tujuan pelanggan dengan menggunakan aplikasi smartphone.

Pengertian dari ojek online berbeda dengan ojek konvensional. Walaupun dalam prakteknya sama tetapi berbeda cara pemesananannya ojek online menggunakan aplikasi sementara ojek konvensional hanya menunggu dan menerima panggilan

Walaupun beberapa perusahaan menyelenggarakan dalam pemesanan ojek, perusahaan tidak dapat disebut sebagai perusahaan ojek online.

Ada 6 faktor yang menjadi pembatas dan penghalang antara ojek online dan ojek kovensional, 6 faktor tersebut terdiri dari:

1. Perilaku terhadap penumpang

2. Teknologi

3. Finansial

4. Kelengkapan

5. Informasi dan

6. Paguyuban.

\section{Metode Penelitian}

Penelitian ini adalah penelitian deskriptif. Penelitian deskriptif adalah penelitian yang menggambarkan objek atau peristiwa yang bertujuan untuk mengetahui keadaan yang terjadi pada saat sekarang. Pada penelitian ini, peneliti ingin memperoleh gambaran serta solusi untuk barrier business yang terjadi pada ojek konvensional. Metode yang digunakan dalam penelitian ini adalah metode kualitatif. penelitian kualitatif adalah penelitian yang bermaksud untuk memahami fenomena yang dialami oleh subjek penelitian misalnya perilaku, persepsi, motivasi, tindakan dan lain-lain secara holistik.

Keenam faktor hambatan tersebut akan diukur kepada 36 responden, pengambilan responden, dipilih berdasarkan rumus berikut: Slovin (Devega, 2014)

$$
n=\frac{N}{1+N e^{2}}
$$

Variabel dalam penelitian ini terdiri dari variabel $X$ dan $Y$, variable $X$ dalam penelitian ini adalah hambatan adopsi aplikasi online terhadap pengemudi ojek konvensional. Variable $Y$ dalam penelitian ini adalah hambatan-hambatan adopsi aplikasi terhadap pengemudi ojek konvensional. Kedua variable tersebut akan disusun dalam sebuah kuesioner yang akan diisi oleh pengemudi ojek konvensional.

Angket penelitian yang digunakan dalam penelitian ini adalah kuesioner. Kuesioner adalah suatu daftar pertanyaan yang harus di isi oleh responden sebagai sarana untuk mengumpulkan informasi tentang perilaku, karakteristik, keyakinan dan sikap sekelompok orang atau organisasi.

Tingkat Skala Penilaian Kuesioner Penelitian Hambatan Adopsi Aplikasi Online Oleh Pengemudi Ojek Konvensional di Pusat Kota Bandung.

Tabel 1 Skala Penilaian Kuesioner

\begin{tabular}{|l|l|l|}
\hline No & Tingkat skala & Keterangan \\
\hline 1 & SS & Sangat Setuju \\
\hline 2 & S & Setuju \\
\hline 3 & RR & Ragu-Ragu \\
\hline 3 & TS & Tidak Setuju \\
\hline 4 & STS & Sangat Tidak Setuju \\
\hline
\end{tabular}

Sumber: Devega, 2014 
Pengolahan data pada penelitian ini menggunakan MS. Excel dan SPSS 22. Data yang diperoleh ditabulasi dan diolah menggunakan MS. Excel dan SPSS 22, untuk memperoleh analisis frekuensi pada setiap butir pertanyaan dan analisis deskriptif pada data.

\section{Hasil dan Analisis}

Kuesioner mulai dibagikan kepada responden 6 April 2018 sampai 13 April 2018 di 4 (empat) wilayah yang ada di Bandung dan sekitarnya, antara lain : wilayah Cikadut, Terminal Lewi panjang, Cikutra dan Pasteur. Hasil penelitian dikumpulkan sendiri oleh penulis pada hari yang sama. Kuesioner sudah lengkap diisi oleh 36 responden pada 13 April 2018.

Pada bagian ini, akan dijelaskan identitas para responden, terkait dengan pendidikan, umur dan jenis kelamin. Penggolongan ini dilakukan agar dapat mengetahui dengan jelas gambaran responden sebagai objek penelitian.

Penggolongan Responden Berdasarkan Pendidikan Terakhir

Tabel 2 Responden berdasarkan Pendidikan Akhnir

\begin{tabular}{|l|l|l|}
\hline Pendidikan Terakhir & Jumlah (orang) & Persentase (\%) \\
\hline SD & 20 orang & $56 \%$ \\
\hline SMP & 16 orang & $44 \%$ \\
\hline SMA & - & - \\
\hline S1 Sederajat & - & - \\
\hline
\end{tabular}

Penggolongan Responden Berdasarkan Umur

Tabel 3 Responden Berdasarkan Umur

\begin{tabular}{|l|l|l|}
\hline Umur & Jumlah (orang) & Persentase $(\%)$ \\
\hline$>20$ tahun & 2 orang & $6 \%$ \\
\hline$>30$ tahun & 8 orang & $22 \%$ \\
\hline$>40$ tahun & 8 orang & $22 \%$ \\
\hline$>50$ tahun & 11 orang & $30 \%$ \\
\hline$>60$ tahun & 5 orang & $14 \%$ \\
\hline$>70$ tahun & 2 orang & $6 \%$ \\
\hline
\end{tabular}

Penggolongan Responden Berdasarkan Jenis Kelamin Tabel 4 Responden Berdasarkan Pendidikan Terakhir

\begin{tabular}{|l|l|l|}
\hline Jenis Kelamin & Jumlah (orang) & Persentase (\%) \\
\hline Laki -laki & 36 orang & $100 \%$ \\
\hline Perempuan & - & - \\
\hline
\end{tabular}

Hasil dari kuesioner yang dijawab pada 36 kuesioner diatas diuji, dengan hasil sebagai berikut:

\section{Uji Validitas}

Keenam faktor hambatan diuji dengan uji validitas. Nilai validitas yang dihitung pada uji validitas, apabila mendapatkan R Hitung $>0.01$ maka butir soal valid, namun jika R Hitung $<0.01$ maka butir soal tidak valid dan gugur. Uji validitas dilakukan dengan menggunakan SPSS 22.00 dan mendapatkan $\mathrm{R}$ hitung seperti pada tabel berikut.

Tabel 5 Hasil Uji Validitas

\begin{tabular}{|l|l|l|l|}
\hline No Soal & R.Hitung & Syarat & Keterangan \\
\hline 1 & 0.232 & $>0.01$ & Soal Valid \\
\hline 2 & 0.452 & $>0.01$ & Soal Valid \\
\hline 3 & 0.702 & $>0.01$ & Soal Valid \\
\hline 4 & 0.260 & $>0.01$ & Soal Valid \\
\hline 5 & 0.691 & $>0.01$ & Soal Valid \\
\hline 6 & 0.023 & $>0.01$ & Soal Valid \\
\hline 7 & 0.181 & $>0.01$ & Soal Valid \\
\hline 8 & 0.693 & $>0.01$ & Soal Valid \\
\hline
\end{tabular}




\begin{tabular}{|l|l|l|l|}
\hline No Soal & R.Hitung & Syarat & Keterangan \\
\hline 9 & 0.441 & $>0.01$ & Soal Valid \\
\hline 10 & 0.579 & $>0.01$ & Soal Valid \\
\hline 11 & 0.693 & $>0.01$ & Soal Valid \\
\hline 12 & 0.857 & $>0.01$ & Soal Valid \\
\hline 13 & 0.514 & $>0.01$ & Soal Valid \\
\hline 14 & 0.670 & $>0.01$ & Soal Valid \\
\hline 15 & 0.576 & $>0.01$ & Soal Valid \\
\hline 16 & 0.023 & $>0.01$ & Soal Valid \\
\hline 17 & 0.051 & $>0.01$ & Soal Valid \\
\hline 18 & 0.150 & $>0.01$ & Soal Valid \\
\hline 19 & 0.240 & $>0.01$ & Soal Valid \\
\hline 20 & 0.315 & $>0.01$ & Soal Valid \\
\hline 21 & 0.336 & $>0.01$ & Soal Valid \\
\hline 22 & 0.328 & $>0.01$ & Soal Valid \\
\hline 23 & 0.702 & $>0.01$ & Soal Valid \\
\hline 24 & 0.556 & $>0.01$ & Soal Valid \\
\hline 25 & 0.514 & $>0.01$ & Soal Valid \\
\hline 26 & 0.145 & $>0.01$ & Soal Valid \\
\hline 27 & 0.542 & $>0.01$ & Soal Valid \\
\hline 28 & 0.091 & $>0.01$ & Soal Valid \\
\hline 29 & 0.567 & $>0.01$ & Soal Valid \\
\hline 30 & 0.219 & $>0.01$ & Soal Valid \\
\hline 31 & 1 & $>0.01$ & Soal Valid \\
\hline
\end{tabular}

Untuk uji validitas yang digunakan uji factor atau $\mathrm{R}$ kritis sesuai dengan teori. Syarat yang digunakan pearson correlation lebih besar dari R kritis 0,01, jika kurang dari 0,01 maka soal pada instrument dianggap tidak valid dan gugur atau tidak dapat dipakai. Tabel di atas disimpulkan bahwa semua soal pada kuesioner adalah soal yang valid.

\section{Uji Reliabilitas}

Reliabilitas menunjukkan sejauh mana suatu alat ukur dipercaya. Bila suatu alat ukur dipakai untuk mengukur gejala. Uji reliabilitas menunjukkan konsistensi suatu alat ukur didalam mengukur gejala yang sama.

Tabel 6 Reliabilitas pada Variabel Perilaku Reliability Statistics

\begin{tabular}{|l|l|}
\hline Cronbach's Alpha & N of Items \\
\hline 378 & 9 \\
\hline
\end{tabular}

Tabel variabel perilaku menghasilkan nilai cronbach's Alpha sebesar 0.378. Total item sebanyak 9.

Tabel 7 Reliabilitas pada Variabel Teknologi

Reliability Statistics

\begin{tabular}{|l|l|}
\hline Cronbach's Alpha & N of Items \\
\hline 349 & 5 \\
\hline
\end{tabular}

Tabel variabel perilaku menghasilkan nilai cronbach's Alpha sebesar 0.349. Total item sebanyak 5.

Tabel 8 Reabillitas Pada Variabel Finansial

Reliability Statistics

\begin{tabular}{|l|l|}
\hline Cronbach's Alpha ${ }^{a}$ & N of Items \\
\hline 0,438 & 4 \\
\hline
\end{tabular}


Tabel variabel perilaku menghasilkan nilai cronbach's Alpha sebesar 0.438 . Total item sebanyak 4.

Tabel 9 Reliabilitas pada Varabel Kelengkapan

Reliability Statistics

\begin{tabular}{|l|l|}
\hline Cronbach's Alpha & N of Items \\
\hline 524 & 5 \\
\hline
\end{tabular}

Tabel variabel perilaku menghasilkan nilai cronbach's Alpha sebesar 0.524 . Total item sebanyak 5.

Tabel 10 Reliabilitas Pada Variabel Informasi

Reliability Statistics

\begin{tabular}{|l|l|}
\hline Cronbach's Alpha & N of Items \\
\hline 411 & 3 \\
\hline
\end{tabular}

Tabel variabel perilaku menghasilkan nilai cronbach's Alpha sebesar 0.411 . Total item sebanyak 3.

Tabel 11 Reliabilitas pada Variabel Paguyuban

Reliability Statistics

\begin{tabular}{|l|l|}
\hline Cronbach's Alpha & N of Items \\
\hline 303 & 5 \\
\hline
\end{tabular}

Tabel variabel perilaku menghasilkan nilai cronbach's Alpha sebesar 0.303 . Total item sebanyak 5 .

Nilai yang dihitung yaitu pada bagian Cronbach's Alpha, apabila di dapatkan $>0.30$ berarti baik, $>0.40$ - > 0.50 cukup baik, sehingga dijadikan tabel sebagai berikut.

Tabel 12 Hasil Uji Reliabilitas

\begin{tabular}{|l|l|l|l|}
\hline No & Varibel & Hasil Uji & Keterangan \\
\hline 1 & Perilaku & 0.378 & Diterima \\
\hline 2 & Teknologi & 0.349 & Diterima \\
\hline 3 & Finansial & 0.438 & Diterima \\
\hline 4 & Kelengkapan & 0.524 & Diterima \\
\hline 5 & Informasi & 0.411 & Diterima \\
\hline 6 & Paguyuban & 0.303 & Diterima \\
\hline
\end{tabular}

Tabel di atas menunjukkan hasil reliabilitas dari setiap variable lebih dari 0.30 , artinya setiap variabel memberikan kesimpulan yang baik dan reliabel.

\section{Statistik Deskripsi}

Statistik deskripsi adalah metode penyajian data untuk menaksirkan kualitas data variabel hambatan, terdiri dari (mean dan simpangan baku). Interpretasi setiap simpangan baku dapat dilihat pada tabel berikut dan dapat dilihat pada grafik dengan total terbanyak.

Pada bagian ini, data yang diperoleh akan ditabulasi sesuai dengan jawaban para responden yang ada dalam kuesioner. Dalam pengolahan data, peryataan-peryataan tersebut diberi skor yang menujukkan tingkat setuju dengan nilai pengukuran 1 sampai 5 . Pernyataan tersebut berhubungan dengan hambatan para pengemudi ojek konvensional untuk tidak mengadopsi aplikasi online. Data diolah menggunakan SPSS 22.00, yang menghasilkan data sebagai berikut:

Tabel 13 Analisis Deskriptif

Descriptive Statistics
\begin{tabular}{|lllllll|}
\hline \multicolumn{1}{|c|}{} & $\mathrm{N}$ & Minimum & Maximum & Mean & Std. Deviation \\
\hline jenis kelamin & 37 & 1,0 & 36,0 & 1,946 & 5,7540 \\
umur & 37 & 1,0 & 123,0 & 6,649 & 19,7008 \\
pendidikan Terakhr & 37 & 1,0 & 52,0 & 2,811 & 8,3261 \\
1 & 37 & 1,0 & 82,0 & 4,405 & 13,1750 \\
2 & 37 & 1,0 & 124,0 & 6,649 & 19,8623 \\
3 & 37 & 4,0 & 172,0 & 9,216 & 27,5087 \\
4 & 37 & 1,0 & 138,0 & 7,351 & 22,1048
\end{tabular}




\begin{tabular}{|llllll|}
5 & 37 & 1,0 & 89,0 & 4,676 & 14,2907 \\
6 & 37 & 1,0 & 115,0 & 6,054 & 18,4420 \\
7 & 37 & 1,0 & 122,0 & 6,405 & 19,5625 \\
8 & 37 & 1,0 & 119,0 & 6,216 & 19,0979 \\
\hline 9 & 37 & 1,0 & 95,0 & 4,892 & 15,2785 \\
10 & 37 & 1,0 & 129,0 & 6,703 & 20,7001 \\
11 & 37 & 1,0 & 87,0 & 4,405 & 14,0049 \\
12 & 37 & 1,0 & 83,0 & 4,162 & 13,3656 \\
13 & 37 & 1,0 & 141,0 & 7,270 & 22,6147 \\
14 & 37 & 4,0 & 183,0 & 9,514 & 29,3169 \\
15 & 37 & 1,0 & 90,0 & 4,459 & 14,5423 \\
16 & 37 & 1,0 & 73,0 & 3,514 & 11,7724 \\
17 & 37 & 1,0 & 160,0 & 8,189 & 25,6567 \\
18 & 37 & 4,0 & 164,0 & 8,378 & 26,2957 \\
19 & 37 & 1,0 & 135,0 & 6,784 & 21,7129 \\
20 & 37 & 1,0 & 170,0 & 8,649 & 27,2745 \\
21 & 37 & 1,0 & 160,0 & 8,081 & 25,7017 \\
22 & 37 & 1,0 & 162,0 & 8,162 & 26,0198 \\
23 & 37 & 1,0 & 132,0 & 6,514 & 21,2755 \\
24 & 37 & 1,0 & 99,0 & 4,703 & 15,9824 \\
25 & 37 & 1,0 & 96,0 & 4,514 & 15,5074 \\
26 & 37 & 1,0 & 171,0 & 8,541 & 27,4688 \\
27 & 37 & 4,0 & 191,0 & 9,595 & 30,6553 \\
28 & 37 & 4,0 & 196,0 & 9,838 & 31,4585 \\
29 & 37 & 4,0 & 193,0 & 9,649 & 30,9841 \\
30 & 37 & 4,0 & 201,0 & 10,054 & 32,2662 \\
31 & 37 & 1,0 & 188,0 & 9,324 & 30,2049 \\
Valid N (listwise) & 37 & & & & \\
\hline
\end{tabular}

Berdasarkan data statistik diatas dapat dilihat jawaban responden dari berbagai pertanyaan. Pertanyaan pada kuesioner dari nomor 1 sampai nomor 31 dijawab oleh responden dengan variatif, karena pertanyaan pada kuesioner memiliki standar deviasi yang lebih besar dibanding dengan ratarata.

\section{Analisis Hambatan}

Pada bagian penulis memberikan analisis hambatan sesuai dengan range simpangan baku variabel pertanyaan yang dapat dilihat melalui tabel berikut ini.

Tabel 14 Hasil Uji Analisis Deskriptif

\begin{tabular}{|l|l|l|l|l|l|}
\hline Variabel & $\begin{array}{l}\text { Butir } \\
\text { pertanyaan }\end{array}$ & $\begin{array}{l}\text { Jumlah } \\
\text { Soal }\end{array}$ & N & Range Mean & $\begin{array}{l}\text { Range } \\
\text { Simpangan Baku }\end{array}$ \\
\hline Perilaku & No 1-9 & 9 & 36 & $4,405-9,216$ & $13,17-27,50$ \\
\hline Teknologi & No $10-14$ & 5 & 36 & $4,162-9.514$ & $13,36-29,31$ \\
\hline Finansial & No $15-18$ & 4 & 36 & $3,514-8,378$ & $11,77-26,29$ \\
\hline Kelengkapan & No $19-23$ & 5 & 36 & $6,514-8,649$ & $21,37-27,27$ \\
\hline Informasi & No $24-26$ & 3 & 36 & $4,514-8,541$ & $15,50-27,46$ \\
\hline Paguyuban & No 27-31 & 5 & 36 & $9,324-10,054$ & $30,20-32,26$ \\
\hline
\end{tabular}

Dari tabel deskriptif diatas, dapat dilihat seluruh variable memiliki simpangan baku yang lebih besar dari mean, maka dinyatakan bahwa seluruh variabel adalah hambatan, dan hambatan yang paling besar berada di simpangan baku atau kemencengan yang paling besar, berada di variabel paguyuban. 


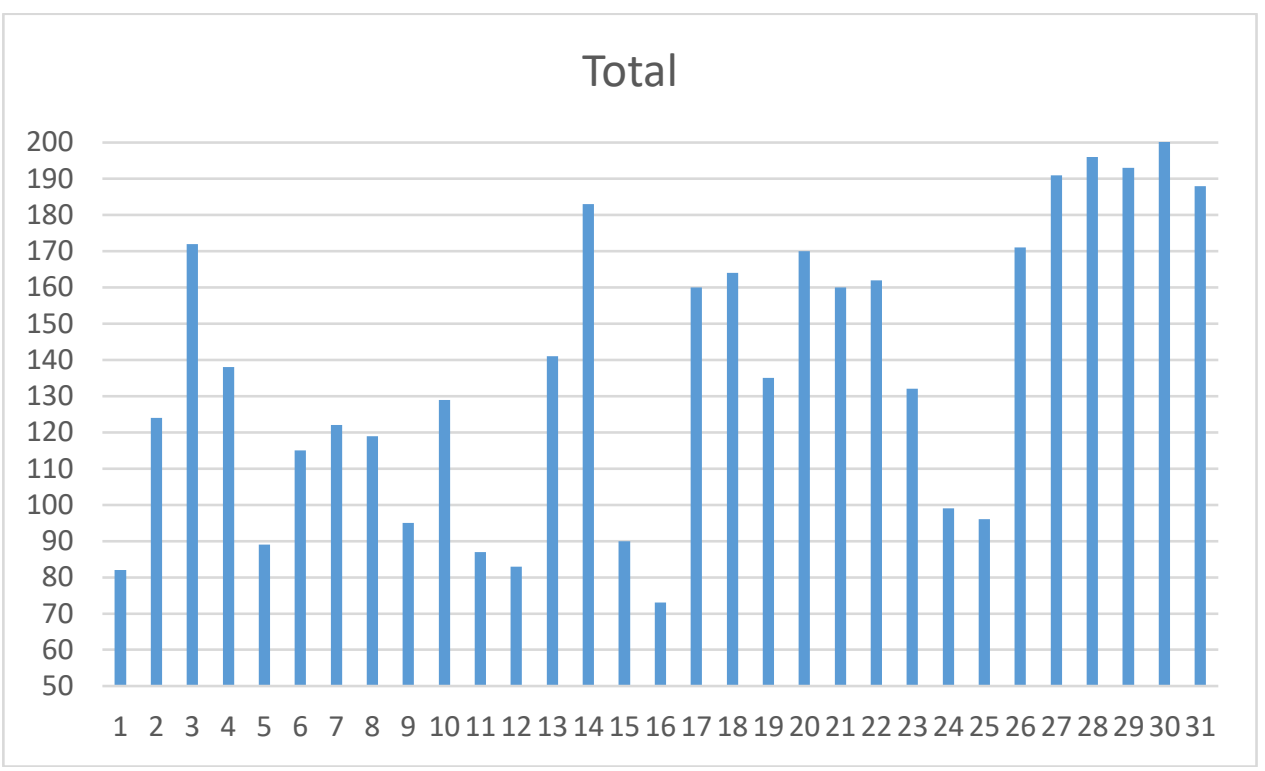

Gambar 1 Grafik Statistik Deskriptif Per Soal Kuesioner

Grafik diatas disusun berdasarkan total atau jumlah dari pernyataan kuesioner sesuai dengan urutan dari nomor 1 sampai 31, dengan total terendah adalah 73 pada soal nomor 16 pada variabel hambatan finansial dan total tertinggi adalah 201 pada soal nomor 30 pada variabel peguyuban.

\section{Kesimpulan dan Saran \\ Kesimpulan}

Kesimpulan yang didapatkan dari penelitian ini adalah:

1. Teknologi juga menjadi hambatan bagi para pengemudi ojek konvensional untuk mengadopsi teknologi ojek online, dimana mereka masih susah mengakses internet dan terhubung kepada teknologi, variabel teknologi diukur oleh pertanyaan nomor 10-14 dengan simpangan baku 13,36-29,31Faktor teknologi, variabel teknologi diukur oleh pertanyaan nomor 10-14 dengan simpangan baku 13,36-29,31

2. Finansial juga menjadi hambatan bagi para pengemudi ojek konvensional untuk mengadopsi teknologi ojek online, dimana mereka masih keberatan untuk menambah modal usaha seperti menyediakan helm, jas hujan dan masker kepada penumpang, variabel Finansial diukur oleh pertanyaan nomor 15-18 dengan simpangan baku 11,77-26,29.

3. Kelengkapan juga menjadi hambatan bagi para pengemudi ojek konvensional untuk mengadopsi teknologi ojek online, dimana sebagian dari mereka belum melengkapi surat berkendara dan belum rutin memberikan service motor bagi kenyamanan penumpang, variabel Kelengkapan diukur oleh pertanyaan nomor 19-23 dengan simpangan baku 21,37-27,27.

4. Informasi ojek online juga menjadi hambatan bagi para pengemudi ojek konvensional untuk mengadopsi teknologi ojek online, dimana mereka masih belum bisa bersaing dengan ojek online, variabel Informasi diukur oleh pertanyaan nomor 24-26 dengan simpangan baku 15,50$27,46$.

5. Paguyuban adalah hambatan yang paling besar bagi para pengemudi ojek konvensional untuk mengadopsi teknologi ojek online, dimana mereka masih nyaman menunggu penumpang di pangkalan karena kebersamaan terhadap sesama pengemudi dianggap memperkecil persaingan dalam mencari penumpang, variabel paguyuban diukur oleh pertanyaan nomor 2731 dengan simpangan baku 30,20-32,26

6. Untuk faktor yang terbesar hambatan mengadopsi aplikasi ojek online adalah faktor paguyuban, dan solusi mengatasi faktor hambatan tersebut bahwa ojek online mempunyai faktor paguyuban sehingga pengemudi ojek konvensional dapat bergabung dalam menjalin sistem paguyuban sesuai dengan sistem yang di buat oleh ojek online.

\section{Saran}

Berdasarkan kesimpulan yang diperoleh dari hasil analisis data, maka penulis mencoba memberi saran untuk mengurangi hambatan pengadopsian aplikasi online. 
1. Pendidikan adalah faktor yang cukup penting untuk meningkatkan kemajuan berfikir dari masyarakat, juga adalah salah satu modal untuk mempunyai suatu pekerjaan yang produktif dan efisisin

2. Seluruh hambatan sesuai variabel yang diteliti akan dapat dikurangi dengan modal mendapat pendidikan dengan cukup baik untuk penunjang pekerjaan.

3. Cara berfikir dan inovasi dibutuhkan dalam kehidupan di era globalisasi. Paguyuban adalah salah satu halangan dan hambatan yang terbesar bagi para pengemudi untuk mengadopsi aplikasi, karena kebersamaan antara para pengemudi dianggap mampu mengurangi persaingan.

\section{Referensi}

1. Ahrika. (2017). ANALISIS KONDISI PENDAPATAN OJEK KONVENSIONAL TERHADAP KEBERADAAN OJEK ONLINE.

2. Annor, F. F. (2016). PERLINDUNGAN HUKUM TERHADAP PENUMPANG OJEK ONLINE(GO-JEK) DI YOGYAKARTA. Yogyakarta.

3. Bahar, L. D. (2014). HAMBATAN ADOPSI TEKNOLOGI INSEMINASI BUATAN OLEH PETERNAK SAPI BALI DI KECAMATAN SOPPENG RIAJA KABUPATEN BARRU. Makkasar.

4. Butler, D. L., \& sellbom, M. (2002). BARRIER TO ADOPTION TECNOLOGY. Indiana.

5. BARRIER TO B2C SEGMENT OF E-BussinesS (M, B. Khan, (E-mail: mkhan@csulb.edu), California State University Volume 2, Number 6

6. METDODOLOGI PENELITIAN PADA BIDANG ILMU KOMPUTER DAN TEKNOLOGI INFORMASI (Zainal A. Hasibuan, PHD) Tahun 2007.

7. KOMUNIKASI PEMASARAN TRANSPORTASI ONLINE NGUBERJEK (Apsari Wahyu Kurniati) RASIONAL OJEK KONVENSIONAL DALAM MEMPERTAHANKAN EKSTENSI DI TENGAH GOJEK DI KOTA SURABAYA Surabaya (Hendita Doni P) vol:4, no 3 (2016)

8. PERSEPSI MASYARAKAT TERHADAP PENGGUNAAN TRANSPORTASI ONLINE (GO_JEK) Di SURABAYA Anis Agustin (2007) Volume 6, nomor 9 Kurnia Sari Aziza Driver GO_JEK BISA RAIH PENGHASILAN Rp 8 JUTA TIAP BULAN Kompas.com 2017 Ahrika (2007).

9. ANALISIS KONDISI PENDAPATAN OJEK KONVENSIONAL TERHADAP KEBERADAAN OJEK ONLINE.

10. Bahar, LD. (20014). HAMBATAN ADOPSI TEKNOLOGI INSENMINASI BUATAN OLEH PETERNAK SAPI BALI DI KECAMATAN RIAJA KABUPATEN BARRU. Makasar

11. Igbal,Jeko. 2015. ALASAN MENGAPA OJEK PANGKALAN OGAH GABUNG GOJEK. PENGERTIAN OJEK ONLINE Menurut Sudut Hukum.com Diakses Pada tanggal 27April 2018 